\title{
PKM Pendampingan Pengembangan Media Pembelajaran Berbasis Lingkungan Pada Materi Bahasa Arab di Madrasah
}

\author{
Sulton Firdaus ${ }^{1}$, Nafahatus Sahariyyah², Elok Azimatuz Zahroh³, \\ Dwi Riskiyanti ${ }^{4}$, Zahrotul Aini ${ }^{5}$, Anwar Nuris $^{6}$ \\ Universitas Nurul Jadid Paiton Probolinggo 123456 \\ sulton.firdaus.1984@gmail.com ${ }^{1}$.. navahatus06@gmail.com²., elokazimatuzzahro@gmail.com³ .. \\ yanti240200@gmail.com ${ }^{4}$,. perhiasanmataku25@gmail.com ${ }^{5}$.. anwarnuriez@gmail.com ${ }^{6}$
}

Submission: 15/08/2021 Received: 23/08/2021 Published: 31/12/2021

\section{Keywords:}

Learning, Media, Environment.
Katakunci:

Pembelajaran, Media, Lingkungan
Abstract. Learning Arabic is one of the materials in many madrasas that require innovation and creation as well as full attention in helping students learn easily and happily. The design of Arabic learning media that is suitable for students both from the aspect of age, background and level of language needs is a necessity that must be prepared by the teacher. The preparation of learning media on environment-based Arabic language material seeks to achieve learning objectives properly and effectively. Efforts to make this happen, we KKN students together with our supervisors, through Community Service activities at Madrash Tsanawiyah Nurul Jadid have the aim of providing insight and experience in designing and designing an Arabic language learning media with two forms of activity, the first is providing material and the second preparation of environmental-based learning media in class VII odd semester of the 2020/2021 academic year.

Abstrak. Pembelajaran Bahasa Arab merupakan satu diantara materi yang ada di banyak madrasah yang memerlukan inovasi dan kreasi serta perhatian penuh dalam membantu siswa-siswi belajar dengan mudah dan senang. Disain media pembelajaran bahasa arab yang berkesesuain dengan peserta didik baik dari aspek usia, latar belakang dan tingkat kebutuhan berbahasa merupakan keniscayaan yang harus dipersiapkan oleh guru. Penyusunan Media pembelajaran pada materi bahasa arab berbasis lingkungan ini berupaya untuk mecapai tujuan pembelajaran dengan baik dan efektif. Upaya dari mewujudkan hal tersebut mahasiswa KKN bersama dosen pembimbing, melalui kegiatan Pengabdian Kepada Masyarakat di Madrash Tsanawiyah Nurul Jadid ini memiliki tujuan memberikan wawasan dan pengalaman didalam mendisain dan merancang sebuah media pembelajaran bahasa arab dengan dua bentuk kegiatan, yang pertama pemberian materi dan yang kedua penyusunan media pembelajaran berbasis lingkungan pada kelas VII semester ganjil tahun ajaran 2020/2021. 


\section{Pendahuluan}

Dalam pembelajaran bahasa yang bertemakan lingkungan merupakan salah satu indikasi untuk dapat membentuk kecerdasan hati, pikiran, dan tangan yang mana ketigakompetensi tersebut mempunyai keterkaitan satu dengan yang lainnya.(Tulalessy TT:51)

Pembelajaran bahasa arab dalam prosesnya selain membutuhkan metode, strategi dan upaya yang sungguh-sungguh juga membutuhkan suatu pengalaman bahasa dan lingkungan yang membentuknya, baik secara langsung maupun tidak langsung, dalam bentuk sumber maupun media buatan berbasis lingkungan. (Firdaus 2018: 1)

Dalam Pengamatan awal yang telah tim lakukan di Madrasah Tsanawiyah Nurul Jadid menemukan bahwa buku ajar pada materi bahasa arab yang digunakan masih seperti buku-buku pada umumnya, dalam bentuk isi materi yang sifatnya umum dan belum mecerminkan kehidupan dan lingkungan dimana para siswa berada dan berinteraksi satu sama lain, tema pada masingmasing bab yang ada tidak banyak yang mengangkat soal-soal lingkungan Madrasah Tsanawiyah Nurul Jadid, yang itu dapat menjauhkan siswa-siswi pemelajar dari dunia belajarnya, akibatnya siswa-siswi kurang dapat dengan mudah memahami isi teks, kurang terangsang imajinasi dan fikirannnya dalam membangun nilai materi serta kurang menggugah minat belajar dan semangat mereka.

Berangkat dari permasalahan diatas dan untuk tujuan agar memudahkan siswa-siswi dalam mempelajari materi bahasa arab maka kegiatan pengabdian kepada masyarakat ini mengusung tema Pendampingan Pengambangan Media Pembelajaran berbasis Lingkungan.

\section{Metode}

Kegiatan pengabdian kepada masyarakat ini terlaksana pada tanggal 03 Februari tahun 202103 Septembeer 2021. Kegiatan ini dilakukan dalam bentuk pelatihan dan pendampingan penyusunan Media pembelajaran berbasis Lingkungan dengan melibatkan Kepala Madrasah, Guru-guru Mata Pelajaran Bahasa Arab, dan WAKA Kurikulum Madrasah Tsanawiyah Nurul Jadid Paiton Probolinggo.

Dalam pelaksanaan kegiatan pelatihan rancangan dan persiapan yang dilakukan diawali dengan Pembentukan tim,Pembagian satuan tugas, 
Observasi, Analisis kebutuhan dan Perumusan tujuan kemudian pelaksanan kegiatan dan evaluasi.

Alur dan rancangan pelaksanaan kegiatan pengabdian kepada masyarakat oleh mahasiswa pendidikan bahasa arab Universitas Nurul Jadid dapat dilihat pada gambar 1 berikut:

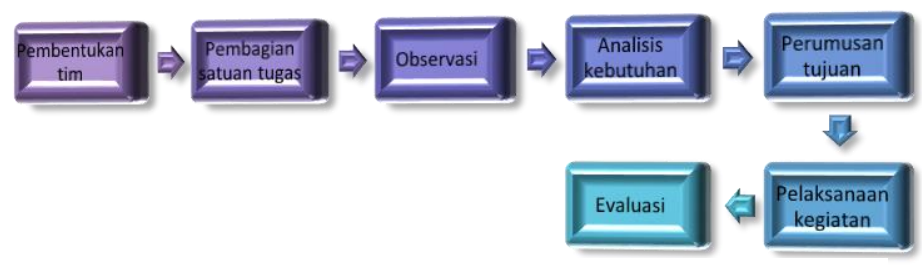

Gambar1: Alur rancang kegiatan PKM

Kemudian dalam penyusunan Media Pembelajaran berbasis Lingkungan peserta pendampingan bersama Dosen Pembimbing merancang dan mengatur scadule pengembangan menggunakan Model pengembangan Dick \& Carey denagn Langkah-langkahberikut: 1. Identifikasi Tujuan, 2. Analisis Instruksional, 3. Analisis Siswa dan lingkungan, 4.Merumuskan Tujuan, 5. Pengembangan Tes acuan Patokan, 6. Pengembangan Siasat Instruksional, 7. Pengembangan Material Instruksional, 8. Merancang dan Melaksanakan Penilaian Formatif, 9.Revisi Instruksional, 10. Merancang dan Melaksanakan Evaluasi Sumatif.

Langkah-langkah pengembangan diatas dapat dilihat pada gambar 2 berikut ini:

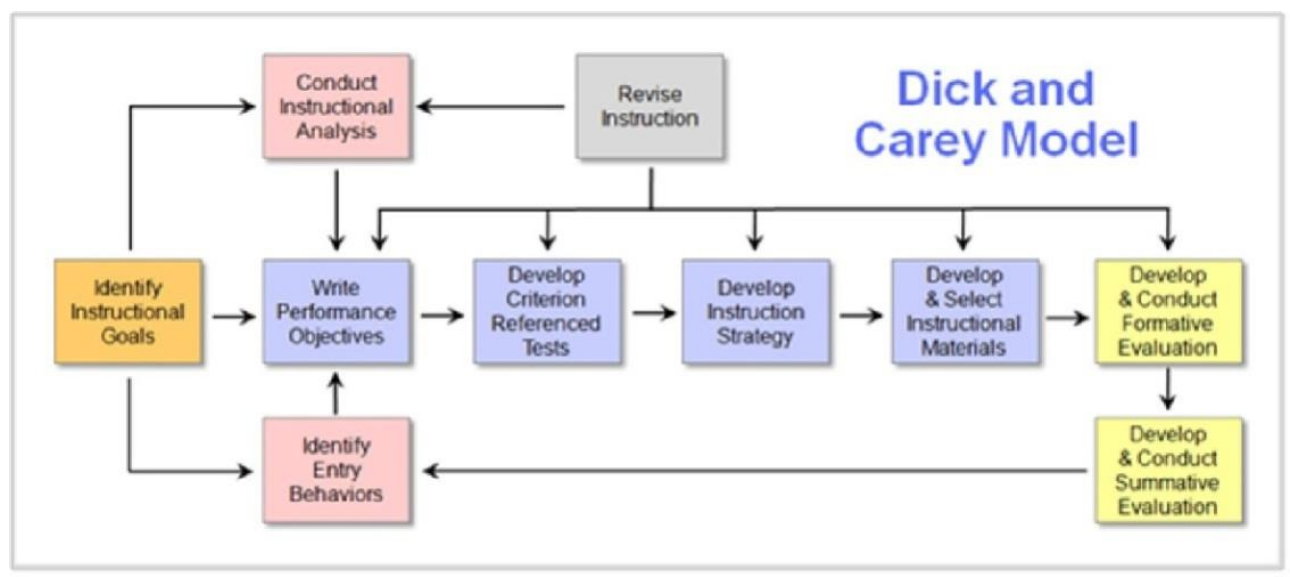

Gambar 2: Langkah-langkah Pengembangan 


\section{Hasil dan Pembahasan}

Kegiatan Pengabdian Kepada masyarakat ini dilaksanakan oleh Peserta Pendampingan Pengembangan media pembelajaran pada materi bahasa arab pada tanggal 03 Februari 2021 s/d tanggal 03 September 2021 dengan Dosen pembimbing Dr. Sulton Firdaus, M.Pd. Kegiatan ini menghasilkan dua kegiatan, yang pertama kegiatan pelatihan pematerian mengenai penyusunan media pembelajaran berbasis lingkungan dan yang kedua pendampingan penyusunan Modul atau buku pembelajaran bahasa arab berbasis lingkungan pada semester ganjil tahun ajaran 2020/2021.

Manfaat dari kegiatan pendampingan penyusunan media pembelajaran ini adalah memberikan wawasan dan pengalaman guru atau tenaga pendidik dalam merancang dan mendisain perangkat pembelajaran terlebih dalam menyusun media pembelajaran yang objektif dan berkesesuaian dengan tingkat kemampuan dan kebutuhan siswa terhadap bahasa yang dipelajari.

Kegiatan PKM ini menghasilkan tiga luaran yaitu: karya tulis Jurnal ilmiah ISSN, Modul Pembelajaran dan Poster.

Berikut gambar 3 pada saat pelaksanaan pelatihan pengenalan materi tentang pengembangan media pembelajaran serta gambar 4 shearing dan analisis serta penentuan tujuan pembelajaran bersama pimpinan Madrasah Tsanawiayh Nurul jadid paiton probolinggo.

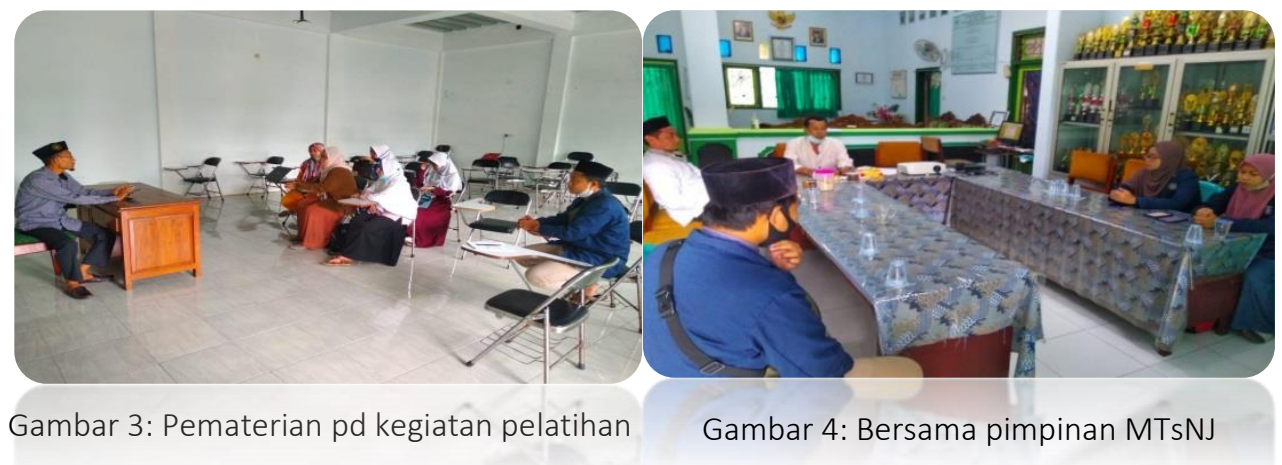

Kemudian pada kegiatan pendampingan penyusunan modul pembelajaran berbasis lingkungan menghasilkan sebuah produk berbentuk buku/modul pada materi bahasa arab semester ganjil tahun ajaran 2020/2021. Berikut foto/cover depan dan daftar isi buku tercantum pada gambar 5 berikut ini: 


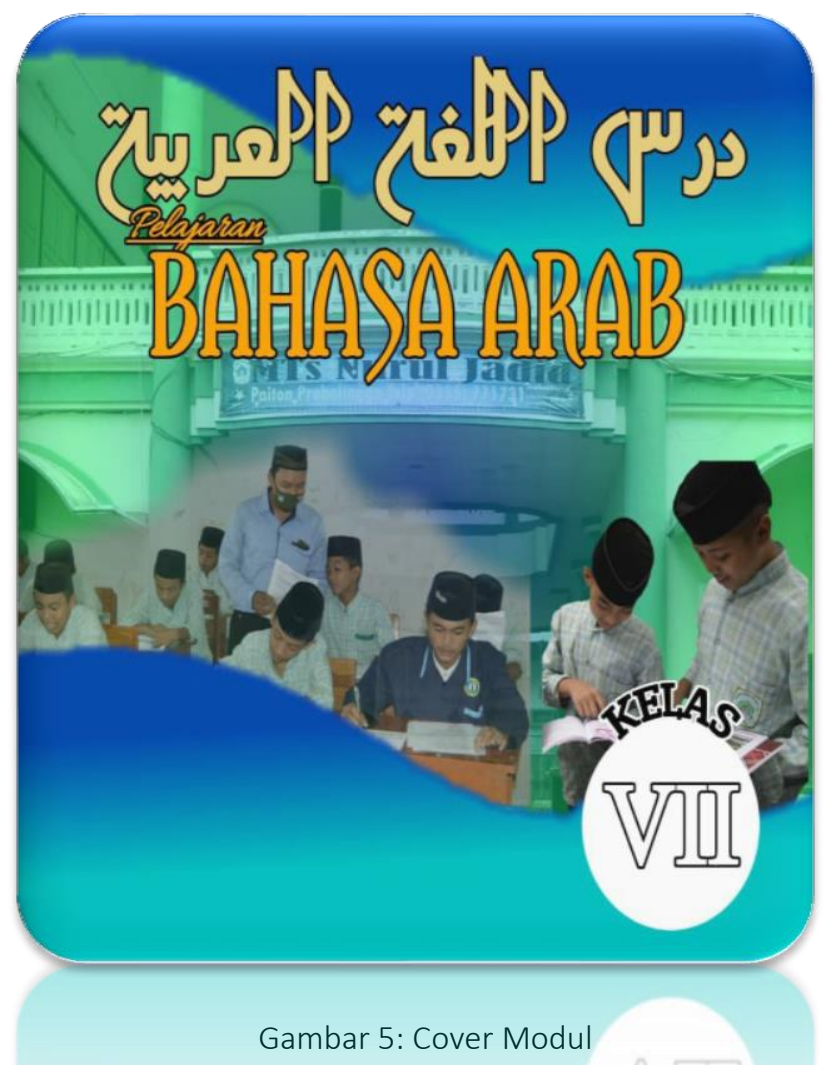

Penggunaan media pembelajaran dalam komunikasi dan interaksi antara pendidik yang mengusung tema tentang lingkungan dalam proses pembelajaran akan memunculkan sentuhan- sentuhan terhadap indera pesertadidik, yang akhirnya akan dapat merangsang ranah kognitif, afektif, dan psikomotor mereka.

Haugen (1972) mengatakan bahwa lingkungan bahasa adalah salah satu media yang saling mempengaruhi antara bahasa dan lingkungan yang bekerja melalui kognisi otak, hati yang secara nyata terwujud dalam pola interaksi verbal, tuturan dan tulisan, dalam komunikasi antar penutur.

Lingkungan diasumsikan memiliki keefektifan belajar dalam meningkatkan kemampuan. Dale (Sadiman, dkk, 1986) mengklasifikasikan pengalaman belajar menurut tingkat yang paling kongkritke yang paling asbtrak, yang dikenal dengan nama Kerucut Pengalaman (core of experience). Menurut Dale, proses belajar yang paling rendah diperoleh melalui pesan verbal, sedangkan yang paling tinggi adalah melalui pengalaman langsung. Ini berarti proses belajar yang efektif bagi penyuluh adalah pengalaman- pengalaman 
yang langsung ditemukan, dirasakan, dan dilakukan di lingkungan tempat tugasnya

\section{Kesimpulan}

Kegiatan pendampingan yang dilakukan oleh mahasiswa Universitas Nurul Jadid yang dilaksanakan di Madrasah Tssanawiyah Nurul Jadid ini dikemas dalam bentuk pertama Pendampingan pematerian dan kedua Penyusunan modul pemebelajaran pada materi bahasa Arab berbasis lingkungan.

Kegiatan ini memberikan wawasan dan pengalaman guru dalam mempersiapkan perangkat pembelajaran dalam membantu kesulitankesulitan anak didik atau siswa dalam belajar bahasa arab dengan bentuk Modul yang disesuaikan dengan tingkat kemampuan siswa serta mengusung topik-topik yang dekat dengan aktifitas sehari-hari siswa dan sesuai dengan kehidupan anak sehari-hari.

\section{Pengakuan}

Melalui kegiatan pendampingan dan penyusunan media pembelajaran berbasis lingkungan ini kepala madrasah beserta waka kurikulum sangat mengapresiasi dan mendukung (nantinya) dalam penyusunan kurikulum yang juga berbasis lingkungan kepesantrenan serta meminta peran aktifnya mahasiswa dan dosen dalam menyongsong perubahan yang akan di lakukan Madrasah Tsanawiayah bersama Yayasan Pondok Pesantren Nurul Jadid Paiton Probolinggo.

\section{Referensi}

Aminudin, (2014). Media Pembelajaran Bahasa Arab.Jurnal Al-Munzir Vol. 7, No. 2, November 2014

Azha A, (2016) Pemanfaatan Media Berbasis Lingkungan Dan Media Standar Laboratorium Pada Pembelajaran Dasar-Dasar Sains Di Program Studi Pendidikan Kimia Ftk Uin Ar-Raniry. Lantanida Journal Vol. 04 No. 2 10.22373/lj.v4i2.1887 ISSN 2356-3133

Nugrawiyati, J. (2016). Lingkungan Sebagai Media Pembelajaran Bahasa Arab. El-Wasathiya: Jurnal Studi Agama, 3(1), 37 - 47. Retrieved 
fromhttp://ejournal.kopertais4.or.id/mataraman/index.php/washati ya/article/view/2005

Riqza M S, Muassomah, (2020) Media Sosial untuk Pembelajaran Bahasa Arab pada Masa Pandemi: Kajian Kualitatif Penggunaan WhatsApp pada Sekolah Dasar di Indonesia. Jurnal Alsina : Journal of Arabic Studies Vol. 2, No. 1 (2020) 71-94 DOI: http://dx.doi.org/10.21580/alsina.2.1.5946

Sholihatin L, (2020) Pengembangan Media Pembelajaran Bahasa Arab Berbasis Aplikasi Plotagon Pada Siswa Ma Nu Petung Panceng Gresik. Proseding Konfrensi Nasional Bahasa Arab VI Malang (ISSN 29575242)

Sujarwo, (TT) Pemanfaatan Media Pembelajaran Berbasis Lingkungan. Jurnal.http://staffnew.uny.ac.id/upload/132304795/pengabdian/me dia-lingkungan.pdf

Tulalessy Quin D, (TT) Pembelajaran Bahasa Berbasis Lingkungan Sebagai Upaya Membangun Kecerdasan Ekologis. Jurnal. Jurusan Pendidikan Bahasa Indonesia FKIP UNIPA- Manokwari 